\title{
Limits to integration in pollution prevention and control
}

Citation for published version (APA):

Peeters, M. G. W. M., \& Oosterhuis, F. H. (2014). Limits to integration in pollution prevention and control. In M. G. W. M. Peeters, \& R. Uylenburg (Eds.), EU environmental legislation: Legal perspectives on regulatory strategies (pp. 91-115). Edward Elgar Publishing. New Horizons in Environmental and Energy Law series https://doi.org/10.4337/9781781954775.00013

Document status and date:

Published: 01/01/2014

DOI:

10.4337/9781781954775.00013

Document Version:

Accepted author manuscript (Peer reviewed / editorial board version)

\section{Please check the document version of this publication:}

- A submitted manuscript is the version of the article upon submission and before peer-review. There can be important differences between the submitted version and the official published version of record.

People interested in the research are advised to contact the author for the final version of the publication, or visit the DOI to the publisher's website.

- The final author version and the galley proof are versions of the publication after peer review.

- The final published version features the final layout of the paper including the volume, issue and page numbers.

Link to publication

\footnotetext{
General rights rights.

- You may freely distribute the URL identifying the publication in the public portal. please follow below link for the End User Agreement:

www.umlib.nl/taverne-license

Take down policy

If you believe that this document breaches copyright please contact us at:

repository@maastrichtuniversity.nl

providing details and we will investigate your claim.
}

Copyright and moral rights for the publications made accessible in the public portal are retained by the authors and/or other copyright owners and it is a condition of accessing publications that users recognise and abide by the legal requirements associated with these

- Users may download and print one copy of any publication from the public portal for the purpose of private study or research.

- You may not further distribute the material or use it for any profit-making activity or commercial gain

If the publication is distributed under the terms of Article $25 \mathrm{fa}$ of the Dutch Copyright Act, indicated by the "Taverne" license above, 


\section{EU environmental legislation: legal perspectives on regulatory strategies}

\section{Chapter:}

Limits to integration in pollution prevention and control

\section{Marjan Peeters and Frans Oosterhuis}

(final draft before editing)

Published in:

Marjan Peeters, Rosa Uylenburg: EU environmental legislation: legal perspectives on regulatory strategies, Edward Elgar, Cheltenham, UK 2014, p. 291- 115

See for the published book: http://www.e-elgar.com/shop/eu-environmental-legislation 
Limits to integration in pollution prevention and control

Frans Oosterhuis and Marjan Peeters

\section{Introduction}

Integration is a magic word in EU policies: the EU itself is a fascinating international integration project, that weaves 27 states (in the near future even more), having a strong emphasis on economic integration through the internal market. ${ }^{1}$ As a result of the EU, legal systems of member states are largely influenced by EU law, and a large part of the environmental legislation applicable in member states has its origin in EU directives. Within environmental law, however, the notion of integration has a very different and specific meaning compared to the general EU notion: it concerns the question how environmental regulatory frameworks can deal comprehensively with the protection of the ecosystem. The main aim of integration in environmental policies is to avoid a fragmented regulatory framework, in which each and every

\footnotetext{
${ }^{1}$ The first sentence of the Preamble to the Treaty on European Union states "Resolved to mark a new stage in the process of European integration undertaken with the establishment of the European Communities". See further about integration in the EU: Damien Chalmers, Gareth Davies, Giorgio Monti (2010), chapter 1. See for a discussion of the role of law in EU integration (not focusing on the "internal" integration in environmental law) Bettina Lange (2008), p 28 etc. In her study, she furthermore examines the decision-making in the EU on the Best Available Technology under the IPPC-directive from a political science and sociology perspective.
} 
aspect (like air, waste, soil, chemicals, energy) is addressed separately. ${ }^{2}$ This environmental integration concept falls apart into "internal" and "external" integration. Internal integration refers to the question how, through regulatory approaches, all the polluting aspects of a certain activity can be regulated in a coherent way. "External integration" concerns the attempt to integrate the aim of environmental protection into other (non-environmental) policies. This idea is codified in art. 11 TFEU, which reads as follows: "Environmental protection requirements must be integrated into the definition and implementation of the Union policies and activities, in particular with a view to promoting sustainable development". ${ }^{3}$ The reference to the concept of sustainable development means that a balance should be achieved between environmental protection, economic, and social concerns. ${ }^{4}$ Hence, here integration is not limited to environmental concerns, and it may be even be the case that social or economic concerns outweigh the environmental ones. ${ }^{5}$ This book contribution focuses at internal integration, and discusses how this paradigm has been applied in EU environmental secondary legislation and what kind of problems may occur with its application in practice. Important practical experience

\footnotetext{
${ }^{2}$ See for a plea for an integrated approach L. Guruswamy (1991), p. 41-56. This article concerns the need for an integrated approach in the sector-oriented environmental legislation of the USA.

${ }^{3}$ Formerly article 6 ECT. See about the principle of external integration: Nele Dhondt (2003).

${ }^{4}$ This concept of sustainable development can play a role in the jurisprudence of the CJEU when it has been mentioned as a criterion for administrative decision-making in secondary legislation: see CJEU C-43/10 [11 September 2012]. See also art. 191(3) fourth indent that urges the Union to take account of the economic and social development of the Union as a whole and the balanced development of its regions.

${ }^{5}$ See for an example C-43/10 [11 September 2012].
} 
with applying the idea of internal integration emerges with administrative authorities in Member States, but empirical research has thus far been limited.

The Integrated Pollution Prevention and Control Directive ${ }^{6}$ (IPPC Directive) from 1996 established the idea that main sources of industrial pollution in the EU have to minimize their adverse impact on the "environment as a whole". ${ }^{7}$ In order to reach the desired environmental protection, the Directive obliges to a command and control approach since member states have to specify the permit conditions, in particular the emission limit values, on the basis of the "best available techniques". ${ }^{8}$ The best available techniques serve in this respect as a tool in order to reach the desired environmental protection through integrated permitting. The basic rationale for the 'holistic' approach by looking at the environment as a whole is the principle that one should not 'rob Peter to pay Paul': it makes little sense to shift pollution from one environmental media (e.g. air) to another (e.g. water or soil). In this vein, one can also consider whether air or water emission abatement techniques which lead to increases in resource use (like energy) or waste production should always be promoted: the idea is that with an integrated approach the different abatement options will be considered in a balanced way, looking at the best outcome for the environment as a whole. The IPPC Directive from 1996 has now been recasted into the Industrial Emissions (IE) Directive from 2010. The IE Directive is in a way as such a product of

\footnotetext{
${ }^{6}$ Directive 96/61/EC OJ L 257, 10.10.1996, codified by Directive 2008/1/EC, OJ L 24, 29.1.2008. The new Directive on Industrial Emissions (2010/75/EU, OJ L 334, 17.12.2010) will replace the IPPC Directive as of 7 January 2014.

${ }^{7}$ The aim of considering the "environment as a whole" appears at many instances in the IPPC and IE directives.

${ }^{8}$ See for a definition art. 2(12) IPPC directive and art. 3(10) IE directive.
} 
legislative integration, as it integrates seven previously existing directives. However, the integrated permit procedure, already prescribed by the IPPC directive, did not change fundamentally with the integration of the IPPC directive into the IE directive. One important change has however been made with regard to the best available techniques (BAT) requirement. The IE directive establishes a stronger role for the BAT documents to be adopted by the European Commission (so-called BAT conclusions): it is now explicitly stated that in a permit emission limit values shall be set to ensure that, under normal operating conditions, emissions do not exceed the emission levels associated with the best available techniques as laid down in the decisions on BAT conclusions (see further section 2.2). ${ }^{9}$

The EU legislator has established the idea of integrated permitting in 1996 and has continued this idea in 2010 with the IE directive. Putting the ideal of an integrative approach into practice is however quite a challenge. In reality, choices may have to be made between different options for the operation of an industrial installation that have different environmental implications. Minimizing air pollution, for instance, may only be achievable by using very energy intensive techniques. Should the emphasis then be on air protection or energy reduction, and can authorities be expected to be able to weigh the different options? Moreover, the scope

\footnotetext{
${ }^{9}$ The following shortcoming has been mentioned in the Commission proposal for the new IE directive: "A detailed analysis has revealed that there are significant shortcomings in the implementation of best available techniques due to vague provisions on BAT in the current legislation, the large degree of flexibility left for competent authorities to deviate from it in the permitting process and the unclear role of the BREFs. As a result, permits issued for implementing the IPPC Directive often include conditions that are not based on BAT as described in the BREFs with little, if any, justification for such deviation.”. European Commission, Proposal for a directive of the European Parliament and of the Council on industrial emissions (integrated pollution prevention and control) Brussels,
} 21.12.2007, COM(2007) 844 final, p. 9. 
and limits of the obligation to undertake an integrative approach are not self-evident: should the permitting authorities, for example, be allowed to interfere with a firm's choices of raw materials or even the design and composition of its products, when aiming at the best outcome for the environment as a whole? And, is it possible to develop best available technique documents, to be adopted by the European Commission, with an integrated approach that can sufficiently guide the decision-making in the individual cases of permitting throughout the whole EU, particularly when different local, environmental and climatic circumstances are at stake? To what extent can the ideal of integration become a reality?

In the following sections we will reflect from a legal and economic perspective on the rationale and implications of the EU's choice for integrated permitting, and address some issues that may arise when trying to put the integration obligation into practice. This is done by analyzing the background and rationale of the integration principle and the way in which it was laid down in the IPPC and IE directives. The experiences and challenges emerging from the application of the integrated approach by permitting authorities are also addressed. We focus in our discussion on the need to reach a substantive integration. ${ }^{10}$

\footnotetext{
${ }^{10}$ See about the distinction between substantive and procedural integration J.H. Jans, H.B. Vedder (2012), p. 361 362. The substantive aim of an integrated approach, which should lead to a high level of protection of the environment as a whole, does not necessarily mean that a single permit requirement has to apply to industries. Member states may choose for several permit systems (like separate permits for air and water emissions) but after all a substantive integrated approach has to be ensured through procedural coordination, which means that an effective integrated approach by all authorities competent for the relevant permits has to be guaranteed (art. 5 IED, notably 5(2)). This substantive integration, which brings along the procedural requirement that different permit schemes should be coordinated, is the focus of our analysis.
} 
The structure of our contribution is as follows. In section 2, we will introduce the legislative framework on integrated permitting that the EU has drawn up. Section 3 discusses, based on legal and economic literature on integration in pollution control, the motives, advantages and disadvantages of the choices that have been made. The implementation and application of the integration obligation in the practice of environmental permitting are the subject of section 4 . Section 5 concludes.

2. The EU's legislative choice towards integrated permitting

2.1 TFEU: No requirement for internal integration

Different from the principle of external integration, codified in art. 11 TFEU, the aim of internal integration has not been stipulated in the TFEU. The TEU and TFEU obligate the EU institutions to pursue a "high level of environmental protection", leaving open what exactly belongs to "the environment". ${ }^{11}$ From a legal perspective, this means that the boundary of the task to preserve, protect and improve the environment is uncertain. Clarifications of the scope of EU environmental law have to be made in the decision-making by the EU-legislator, particularly in defining the scope of the secondary environmental laws in the form of regulations, directives and decisions. Obviously, the scope of each secondary environmental law is important in view of integration: as soon as an environmental legislative act has a limited scope, for instance to air pollution, or, more narrowly, greenhouse gas emissions, an integrative approach will be

\footnotetext{
${ }^{11}$ See the full mandate in art. 191 TFEU.
} 
prevented or may at least become more difficult to achieve in national legislation and administrative practice. However, the aim to undertake an integrated approach in EU environmental law-making has not been prescribed by the TFEU. The case law of the ECJ (now the CJEU) made even clear that integration is not an absolute aim to pursue, by stating that it is not the case that "Article 130r(1) of the Treaty [now 192 TFEU, MP/FO] requires the Community legislature, when it adopts measures to preserve, protect and improve the environment in order to deal with a specific environmental problem, to adopt at the same time measures relating to the environment as a whole". ${ }^{12}$ The court even considered: "It follows that Article 130r(1) of the Treaty authorises the adoption of measures relating solely to certain specified aspects of the environment, provided that such measures contribute to the preservation, protection and improvement of the quality of the environment." ${ }^{13}$ The appellant in the case argued that the adopted regulation on substances that depleted the ozone layer had a too narrow scope, particularly because it did not take into account two fundamental parameters for environment protection which were the "Global Warming Potential" and the "Atmospheric Lifetime" of the ozone depleting substances. The appellant argued that if those factors, relevant for climate protection, were taken into consideration, the non-authorized ozone depleting substances (HCFCs) would be found to be much less harmful than the authorized ones (Halons). However, the court, following a marginal test known as a "manifest error of appraisal" allowed

${ }^{12}$ C-341/95, Bettati v. Safety HiTech [14 July 1998], para 42, regarding Council Regulation 3093/94 of 15 December 1994 on Substances that deplete the ozone layer. At the time of the court decision the EU had signed the UNFCCC (United Nations Framework Convention on Climate Change) from 1992 and had also concluded the Kyoto Protocol.

${ }^{13}$ Par. 43 of C-341/95 
the adoption of measures that relate only to one specific aspect of the environment (ozone layer) leaving out another but important aspect (global warming). In later case law, the CJEU endorsed a step-by-step approach, allowing a narrow scope of an environmental law (in this case greenhouse gas emissions trading, established by directive 2003/87/EC) knowing that more emitters were contributing to the same environmental problem. ${ }^{14}$ In this sense, the Court allowed to focus on only part of the emitters and part of the emissions to a pollution problem as a stage in the legislative process on a complicated matter. The appellant, a steel industry, referred to the fact that its products were competing with products from the aluminium and chemical industry, while these industries were not covered by the legislation. ${ }^{15}$ Arcelor argued that the emissions related to a product should not be considered in isolation, but both the production process and the lifecycle of the product should be taken into consideration. ${ }^{16}$ After all, it might be possible to produce a product directly causing few GHG emissions, but the product may soon have to be replaced - while a product made with a greater GHG emissions may have a longer useful life. This part of the plea can be framed as a quest for an integrated approach but the court followed the idea that a legislator should be able to pursue a step by step approach in such a complex policy dossier as building regulation to fight climate change. These two examples from case law modestly show that through case law it will be hard to reach a more integrated environmental legislation.

\footnotetext{
${ }^{14}$ T-16/04 and C-127/07 (Arcelor) Marjan Peeters (2011).

${ }^{15}$ See para. 156 of T-16/04. This competition occurs inter alia in the manufacture of drink-packaging and car parts.

${ }^{16}$ See para. 148 of T-16/04
} 


\subsection{Integrated permitting as a policy choice of the EU}

The notion of integration has however got strong emphasis in the policy practice of the EU, resulting in the adoption in 1996 of the IPPC directive with the obligation for Member States to implement an integrated permit system for a wide range of industries. The basic idea of this regulatory approach is to conduct a coherent approach to industrial activities in order to provide an effective environmental protection, as has been stated in the preamble:

"Different approaches to controlling emissions into the air, water or soil separately may encourage the shifting of pollution between the various environmental media rather than protecting the environment as a whole.". ${ }^{17}$

The Industrial Emissions Directive (further: IE Directive) adds to this sentence:

"It is, therefore, appropriate to provide for an integrated approach to prevention and control of emissions into air, water and soil, to waste management, to energy efficiency and to accident prevention. Such an approach will also contribute to the achievement of a level playing field in the Union by aligning environmental performance requirements for industrial installations.". ${ }^{18}$

This shows that with the IE directive not only the effective protection of the environment as a whole is aimed at, but that also a market concern is at stake which is to achieve a level playing field by closing the differences of environmental performance requirements for industrial installations. Hence, market integration by means of a level playing field has become part of the integrated permitting approach. In this vein, the IE directive establishes a stronger legal role for

\footnotetext{
${ }^{17}$ Directive 2008/1, preamble paragraph 8.

${ }^{18}$ Directive 2010/75, preamble paragraph 3.
} 
the best available control techniques. The directive obliges to follow a process in which exchange of information on best available technologies takes place among member states, industries and environmental NGO's. ${ }^{19}$ Consequently, the Commission can adopt a decision with conclusions on the best available technology. ${ }^{20}$ These conclusions are important for the decision-making in a permit-procedure: the IE directive prescribes that the competent authority has to set emission limit values that ensure that, under normal operating conditions, emissions do not exceed the emission levels associated with the best available techniques as laid down in the Commission decisions on BAT conclusions. ${ }^{21}$ Hence, the BAT conclusions have to play an important role in the achievement of the integrated approach. There are limited possibilities for the authority to deviate from these Commission conclusions in case the obligations would lead to disproportionately higher costs compared to the environmental benefits. From a viewpoint of integration, it is interesting to note that a derogation from such BAT conclusions by means of less strict emission limit values can be justified in view of the geographical or local environmental conditions. ${ }^{22}$ This under the condition that it is ensured that "no significant

${ }^{19}$ Art. 13 IED.

${ }^{20}$ Art. 3(12) IED: "BAT conclusions' means a document containing the parts of a BAT reference document laying down the conclusions on best available techniques, their description, information to assess their applicability, the emission levels associated with the best available techniques, associated monitoring, associated consumption levels and, where appropriate, relevant site remediation measures".

${ }^{21}$ Art. 15(3) IED.

${ }^{22}$ Art. 15(4) IED. The full text reads: "Such a derogation may apply only where an assessment shows that the achievement of emission levels associated with the best available techniques as described in BAT conclusions would lead to disproportionately higher costs compared to the environmental benefits due to:

(a) the geographical location or the local environmental conditions of the installation concerned; or(b) the technical characteristics of the installation concerned. The competent authority shall document in an annex to the permit conditions the reasons for the application of the first subparagraph including the result of the assessment and the justification for the conditions imposed.The emission limit values set in accordance with the first subparagraph shall, however, not exceed the emission limit values set out in the Annexes to this Directive, where applicable. The competent authority shall in any case ensure that no significant pollution is caused and that a high level of protection 
pollution is caused and that a high level of protection of the environment as a whole is achieved.". ${ }^{23}$ Hence, deviation from BAT conclusions is only possible if the integrative approach is followed, with a high level of protection of the environment as a whole. What this integrative approach, to be determined in the permitting procedure, exactly means stays vague. The Commission may provide guidance on the application of the derogation clause, and it remains to be seen whether and how this possibility for giving further clarity will be used. ${ }^{24}$ Next to this, it will also be interesting to see to what extent judicial control will be applied on the question how a deviation from BAT conclusions can be done in relation to a high protection of the environment as a whole.

Given the increasingly important legal status of the best available control technology in the IE directive, the content of the BAT conclusions will be important for reaching an integrated approach. ${ }^{25}$ Some evidence from practice on the thus far short-falling quality of BAT documents adopted under the IPPC directive will be discussed in section 4 . The IE directive gives now a

of the environment as a whole is achieved. ". A given derogation has to be assessed in case of a reconsideration of the permit conditions (art. 15(4) IE directive).

${ }^{23}$ See again art. 15(4) IED (previous note).

${ }^{24}$ Art. 15(4) IED.

${ }^{25}$ Art. 14(3) reads: "BAT conclusions shall be the reference for setting the permit conditions.". See also the following quote from the proposal for the IE directive: “An integrated approach taking into account cross-media effects in permitting is therefore essential. The central element of such an approach is the implementation of Best Available Techniques (BAT).”, European Commission, Proposal for a directive of the European Parliament and of the Council on industrial emissions (integrated pollution prevention and control) Brussels, 21.12.2007, COM(2007) 844 final, p. 2. 
specific provision in case the BAT conclusions do not deal with all the environmental effects of a specific installation. Where those conclusions do not address all the potential environmental effects of the activity or process, the competent authority shall, after prior consultations with the operator, set the permit conditions on the basis of the best available techniques that it has determined for the activities or processes concerned, by giving special consideration to the criteria listed in Annex III. ${ }^{26}$ One of the criteria refers to the holistic approach: "the need to prevent or reduce to a minimum the overall impact of the emissions on the environment and the risks to it." This means that if BAT conclusions do not cover all potential environmental effects, the permitting authority has the task to determine the best available techniques thereby respecting the need to consider the overall impacts. The permitting authority should also develop such BAT in case an activity or a type of production process carried out within an installation is not covered by any of the BAT conclusions. In sum, as long as BAT conclusions have not been adopted, or are not covering the specific situation for which a permit is requested, the permitting authority faces the task to determine the best available control technology in order to build upon that the permit conditions.

The BREF documents adopted under the IPPC directive before the entry into force of the IE directive will stay applicable until BAT conclusions are adopted under the IE directive. ${ }^{27}$ This however doesn't apply to the articles 15(3) and 15(4) IE directive, which means that the new regime consisting of (1) the requirement to base the emissions limit values on the BAT conclusions and (2) the possibility to deviate from such BAT conclusions is only applicable for

\footnotetext{
${ }^{26}$ Art. 14(6) IED.

${ }^{27}$ Art. 13(7) IED.
} 
the situations for which under the IE directive BAT conclusions have been adopted by the Commission. Until then, the BREF documents adopted under the IPPC directive will stay relevant, although it is not completely clear how, in a legal sense, these BREF documents bind the permitting authorities. ${ }^{28}$

\subsection{Limitation to integration: greenhouse gases}

The IPPC and IE directives do not imply a full integrative consideration of all emissions. A very important limitation has been established with regard to greenhouse gas emissions. With the introduction of the EU wide greenhouse gas emissions trading system by directive 2003/87, the imposition of emission-limit values for $\mathrm{CO}_{2}$ (and other greenhouse gases covered by the emissions trading system) has been forbidden, unless such an emission limit value is necessary in order to ensure that no significant local pollution is caused. ${ }^{29}$ The rationale for this rule is that the functioning of the emissions trading instrument, and hence the freedom of operators to decide whether to reduce emissions or to buy allowances, should not be frustrated by "command and

${ }^{28}$ According to art. 80 the MS have to apply the permit regime from 7 January 2013 onwards. The legal basis for the BREF documents (Best available technique REFerence document) is art. 17 of the IPPC directive. See also case T158/11, Magnesitas de Rubián SA v Parliament and Council asking for annulment of the "individual decision contained in art. 13(7)" of the IE directive (it remains to be seen whether this action is admissible in view of art. 263 TFEU).

${ }^{29}$ See art. 9 IPPC directive, art. 9 IE directive and article 26 Directive 2003/87/EC. The efficient use of energy is formulated as an obligation for the operator to the installation (Art. 3(1)(d) IPPC directive; art. 11(f) IE directive), but the directive leaves to the member states whether or not to put any requirement with regard to that in the permit conditions (art. 9(2) IE directive). 
control" emission limits imposed by the IPPC permit. Member states may however choose to impose in the IPPC permit obligations with regard to energy efficiency of EU ETS installations. ${ }^{30}$ The preamble to the IE directive even explicitly refers to the consideration of energy efficiency in view of conducting an integrated approach. ${ }^{31}$ In addition, the new Energy Efficiency Directive obliges Member States to ensure that industries, also those covered by the IE Directive and the EU ETS, conduct energy efficiency audits. ${ }^{32}$ While energy is explicitly mentioned as one of the focal points of the IPPC and IE directive, it is not obliged to conduct an integrated permit assessment that would lead to energy efficiency requirements. This is a crucial limit to integration, as certain techniques that avoid pollution to the air or water cost energy, but the imposition of energy efficiency measures as such may be prohibited by member states. This leaves us with the question whether the use of energy still may play a role with integrated assessment leading to the determination of inter alia a water or air emission limit value.

Particularly when a Member States has decided to make use of the possibility not to adopt energy efficiency measures into the IPPC or IED permit, the question whether the permitting authority is still competent to take account of energy issues when defining the emissions limit values could be part of a legal dispute. Given the explicit emphasis in the IE directive on energy efficiency being part of an integrated approach, we hold the view that energy considerations should play a role when determining the specific emission limit value for an installation.

\footnotetext{
${ }^{30}$ See the articles mentioned in the previous note.

${ }^{31}$ Preamble 3 of the IE Directive: "It is, therefore, appropriate to provide for an integrated approach to prevention and control of emissions into air, water and soil, to waste management, to energy efficiency and to accident prevention.".

${ }^{32}$ Energy Efficiency Directive 2012/27/EU , article 8 (4).
} 
Also from another perspective there is a need to fine-tune the obligations stemming from the IPPC and IE directive with the EU ETS directive: there is a coordination obligation between the EU ETS directive and the IPPC/IE directive, which means that Member States shall take the necessary measures to ensure that the conditions of, and procedure for, the issuance of a greenhouse gas emissions permit (which permit contains particularly the monitoring obligations for an EU ETS installation) are coordinated with those for the permit provided for in the IPPCdirective. ${ }^{33}$ This coordination is not purely procedural, since the conditions for both permits have to be coordinated. Most likely, this coordination will predominantly take place in view of monitoring techniques.

If an installation is covered by on the one hand the IPPC/IE directive and on the other hand the EU ETS directive, the possibility to include emission limit values for greenhouse gases in the IPPC/IE permit seems to be limited. However, in view of the fact that both directives have been based on article 192(1) TFEU, more stringent emission requirements can be considered by the authorities. It is nevertheless unclear to what extent this is possible, given the fact that both the EU ETS directive and the IPPC/IE directive state that emissions limit values shall not be prescribed for direct greenhouse gas emissions from installations covered by the EU ETS. Can, in such a case, a Member State still make use of article 193 TFEU, and hence for instance impose $\mathrm{CO}_{2}$ emission reduction requirements in an IPPC permit? This is a question on which clarification by the Court is needed (or by a change of the TFEU itself). If we follow the view of Jans and Vedder, the clear harmonizing rule that no emission limit values shall be imposed on gases that are covered by the EU ETS, such more stringent measures in the form of "emission

\footnotetext{
${ }^{33}$ See article 8 of the original EU ETS directive.
} 
limit values" are not possible. ${ }^{34}$ Interestingly, the IE Directive gives the following cryptic direction in the preamble thereby seeming to allow more stringent measures (other than emission limit values): "In accordance with Article 193 of the Treaty on the Functioning of the European Union (TFEU), this Directive does not prevent Member States from maintaining or introducing more stringent protective measures, for example greenhouse gas emission requirements, provided that such measures are compatible with the Treaties and the Commission has been notified.". ${ }^{35}$ Hence, in theory there is a possibility, according to the directive, to adopt greenhouse gas emission requirements in the IE permit. However, the rule that no emission limit values may be imposed has not been changed in the IE directive. Greenhouse gas emission requirements most likely may not take the form of emission limit values in an IE permit (unless the view can be held that a directive cannot restrict art. 193 TFEU).. Those member states that want to go ahead with a more ambitious climate policy and want to impose "greenhouse gas emission requirements" are left with an opaque legislative framework on the EU level. The UK has nevertheless explicitly considered to impose Emission Performance Standards to individual coal fired power plants. ${ }^{36}$ These standards set thresholds for the acceptable level of carbon dioxide emissions per unit of electricity generated for individual power stations. ${ }^{37}$ If such steps will be made, and if greenhouse gas emission requirements are indeed found compatible with EU

\footnotetext{
${ }^{34}$ J.H. Jans, H.B. Vedder (2012), p. 118-121. See for a further analysis L. Squintani et al. (2012), p. 67-88.

${ }^{35}$ IED, preamble, recital 10.

${ }^{36}$ See the UK Department of Energy and Climate Change (2009), A framework for the development of clean coal (consultation document June 2009), London, p. 32.

${ }^{37}$ See for a discussion L. Squintani et al. (2012), p. 67-88.
} 
law, this would mean that the question of how to integrate such specific requirements with the whole environmental performance of an installation will arise.

3. Appreciation of the choice towards integrated permitting in literature

\subsection{Economic perspective}

Comparing apples and oranges is an economist's daily occupation. In that respect, weighing (for instance) air pollution against water pollution is an economic issue as well. Theoretically, the 'optimum' level of pollution is reached when the marginal cost of pollution abatement equals the marginal benefit of the associated environmental improvement. ${ }^{38}$ In the case of multiple environmental media, this optimum should be achieved for each of them simultaneously. Whether or not a certain increase in water pollution should be allowed (if possible given applicable water quality standards) in exchange for lower air emissions is "just" a matter of calculating the costs and (social) benefits of each option. If we knew, for instance, that the monetary value of the environmental damage caused by one unit of pollutant $\mathrm{A}$ is twice the damage caused by one unit of pollutant B, a choice between techniques that reduce both pollutants to different degrees would be simple.

In reality, the various types of environmental pollution do not carry such 'price tags' that would enable the decision maker to decide, in a situation where several alternative potential best available technology options exist, which one should be preferred, seen from an integrated perspective. In order to provide some guidance for such situations, the European Commission

\footnotetext{
${ }^{38}$ See, for instance, Kahn (2005), chapter 3.
} 
has published, under the IPPC directive, a Reference Document on Economics and Cross-Media Effects (ECME) (EC, 2006a).

When it comes to comparing alternatives with different scores on various environmental aspects, the usefulness of the Economics and Cross-Media Effects document seems to be limited. It suggests to compare the relative contribution of each alternative to the total European load of pollutants (or the total EU emissions of the sector involved). For example: one technique might lead to air emissions of methane corresponding to $0.01 \%$ of the total methane emissions to air in the (EU) sector and at the same time, a level of emissions of phenols to water corresponding to $1 \%$ of the total phenol emissions to water in the (EU) sector. Similarly, a second technique might lead to emissions of methane to air corresponding to $0.1 \%$ of the total methane emissions to air in the (EU) sector and emissions of phenols to water corresponding to $0.001 \%$ of the total phenol emissions to water in the (EU) sector. Compared to the first technique, the second thus leads to 10 times higher relative methane emissions to air but 1000 times lower relative phenol emissions to water. $^{39}$

The Economics and Cross-Media Effects document acknowledges the limitations of this approach, pointing to the large uncertainties involved and the need to take local circumstances (such as environmental quality and presence of sensitive receptors) into account. ${ }^{40}$ The latter reference is interesting: under the IPPC directive, article 9(4) enabled to consider such local

\footnotetext{
${ }^{39}$ EC, 2006a, p. 30. Clearly, this approach only facilitates the comparison between the alternative options. The choice is still left to the decision maker: if (s)he attaches a much higher weight to methane emissions than to phenol emissions, (s)he may still opt for the first technique.

${ }^{40}$ EC, 2006a, p. 28.
} 
circumstances in the following text: "Without prejudice to Article 10, the emission limit values and the equivalent parameters and technical measures referred to in paragraph 3 shall be based on the best available techniques, without prescribing the use of any technique or specific technology, but taking into account the technical characteristics of the installation concerned, its geographical location and the local environmental conditions. In all circumstances, the conditions of the permit shall contain provisions on the minimization of long-distance or transboundary pollution and ensure a high level of protection for the environment as a whole.". Under the IE directive, the possibility to take account of such local circumstances seems to be rather limited: this is according to the text of the directive only possible when an assessment shows that the achievement of emission levels associated with the best available techniques as described in BAT conclusions would lead to disproportionately higher costs compared to the environmental benefits due to inter alia the geographical location or the local environmental conditions of the installation concerned. ${ }^{41}$ The Cross Media approach has hence to be interpreted in view of this new legal requirement. Presently, it is unclear if and when the ECME document will be updated.

Leaving less room for permitting authorities to conduct an integrated approach may lead to sub-optimal choices, since there is seemingly less room to take into account the relationship between on the one hand the costs of the technique and on the other hand the benefits to the local environment. The IE approach nonetheless implies that if there is a good local environmental quality, particularly air quality, costly air pollution emission limit values that can be qualified as "disproportional" do not necessarily have to be applied. The crucial question is of course what

\footnotetext{
${ }^{41}$ Art. 15(3) IE Directive.
} 
costs will amount to "disproportional", and to what level this may already be determined in the BAT conclusions.

Styles et al. (2009) have tried to refine the Economics and Cross-Media Effects approach by constructing an 'Environmental Emissions Index' (EEI). The EEI takes into account what happens to the pollutant after it has entered the environment. Weighing different impacts is done by means of a 'distance to target' method (measuring the relative distance between the policy target and the actual level of pollution). Other authors suggest a more economic approach to integrate different environmental aspects in determining BAT. For example, Georgopoulou et al. (2008) present a decision support model to determine the costs and benefits of BAT, in which different emissions are expressed in monetary terms, allowing their mutual comparison as well as a comparison with costs. The number of pollutants included in the model is, however, quite limited. Bréchet and Tulkens (2009) propose a method that aims at optimisation by means of social cost-benefit analysis ${ }^{42}$ at the plant level, including the external cost caused by the plant. Using this approach they developed a decision support tool which they applied to the limestone industry. They concluded that (in this case) the term 'BCAT' (Best Combination of Available Techniques) would be more appropriate than 'BAT'.

While these examples contain interesting attempts at solving the 'apples versus oranges' problem, they do not offer a ready-to-use and widely applicable tool for decision makers. By and large, the number of scales, balances and other weighing devices that the permitting authorities

\footnotetext{
${ }^{42}$ Social cost-benefit analysis is a method of economic analysis that compares all costs and benefits to society of a certain action, including the 'external' cost (i.e. the negative impact on society, such as pollution). Of course, in applying new assessment techniques the limits of the permit competence have to be respected (not all social costst are covered by the current framework).
} 
have at their disposal to assist them in choosing between pollution control techniques with different environmental properties seems to be quite limited. There are hardly any standards for comparisons between pollutants (except for closely related ones, e.g. greenhouse gases and acidifying substances) and for cross-media evaluations (Bohne, 2008a,b). Moreover, it is questionable whether such standards would be appropriate when applied uniformly across the EU. Faure and Lefevere (1996, p. 120), for instance, argue that emission levels should be regulated at a low level of governance, since local circumstances may differ widely and require weighing at the local level.

\subsection{Policy and law perspectives}

What is exactly "integration", and how should the criterion of the protection of the environment as a whole be judged from a legal perspective? The core purpose of the IPPC and IE directive, integration, has not been defined in the legislative texts, and this complicates a potential judicial control on the substantive application of integration by the permitting authorities. Neither the IPPC nor the IE directive provide concrete legal standards against which it can be assessed whether or not integration has been achieved. If a legal requirement is vague, judicial enforcement stays necessarily weak compared to detailed legal obligations. This does not only mean that national courts are limited in testing the national permits against the core aim of the IPPC directive and IE directive, it also means that the Commission is limited in enforcing a substantive integrated approach through the infringement procedure. The lack of a definition of integration in the IPPC is as such no surprise. The literature shows that at the time of the adoption of the IPPC directive, science had not yet provided concrete tools for applying an 
integrated approach in the permitting process. ${ }^{43}$ Conducting an integrated approach weighing different environmental effects, of which not everything can exactly be understood, is a highly complicated task, for which legislative guidance hardly can be developed. Hence, the EU had imposed a regulatory aim on member states (integrated permitting) that because of its vagueness cannot be strongly enforced before the courts. For the courts, the most concrete approach to test whether a permit is compatible with the IPPC and IE framework is to assess the permit against the best available technique documents (BREFS under the IPPC, and BAT conclusions under the IE). However, here the question pops up whether such general documents really reach the aim of an integrated approach, and to what extent case-specific considerations are to be made by the permitting authorities in order to fulfill the ultimate aim of the protection of the environment as a whole. Seemingly, the IPPC-directive left more room for case-specific considerations with the explicit reference to taking into account the technical characteristics of the installation concerned, its geographical location and the local environmental conditions. ${ }^{44}$ Nonetheless, the Commission hardly pays attention to the question whether the aim of integration has been reached in its report on the implementation of the IPPC-directive. ${ }^{45}$ This needs to be understood in view of the severe compliance problems: the Commission had to start infringement procedures against 16 Member States because of a lack of transposition of the IPPC directive in the national legislation. ${ }^{46}$ Moreover, as a result of the lack of progress in the granting and reconsidering of permits, the

\footnotetext{
${ }^{43}$ E. Bohne (2008a). See also L. Breedveld (2000) .

${ }^{44}$ Art. 9(4) IPPC directive.

${ }^{45}$ European Commission (2010).

${ }^{46}$ European Commission (2010) p. 3.
} 
Commission opened infringement cases against 12 Member States. These data show the huge compliance deficit in the EU, which illustrates the lack of support within the member states to alter their national approaches into an integrated permit system based on a technology approach.

But to what extent is the aim of integration anyway executable? A fundamental comment to the holistic approach has been provided by Bohne and Dietze in 2004. They stated: "The holism of the natural world cannot be reflected in our theoretical concepts and analytical methods. Lacks of information and knowledge regarding dose-effect relationships, synergetic and antagonistic effects as well as the interactions among the elements of the environmental systems add to the theoretical and methodological problems posed by incommensurability of environmental goods" ${ }^{47}$ In other terms, the IPPC directive obliges the member states to do something that is hardly executable. The EU has imposed a legal framework in which member states, more particularly the appointed permitting authorities, have to find a way out, thereby of course viewing potential resistance from industries if the integrated approach would lead to less favorable outcomes for them.

Since "integration" or "the protection of the environment as a whole" are vague terms in essence, courts can hardly play a role in enforcing this ultimate aim of the directive. However, if BAT documents are determined, courts could be willing to test the permit-decision against the BAT document. BAT documents are however by nature general, while the permit enables an individual consideration of the specific circumstances of the case. The potential usefulness of the criterion of BAT, and the related BAT guidance documents, has been questioned. Krämer even

\footnotetext{
${ }^{47}$ E. Bohne, D. Dietze (2004) p. 199; See about complexities also M. Doppelhammer (2000) p. 199-200 and L. Guruswamy (1991) p. 55.
} 
states that the IPPC-approach is an illustration of the reluctance to impose harmonized

production criteria. ${ }^{48} \mathrm{He}$ argues for more precise conditions to be imposed on industries. ${ }^{49}$ Bohne however has argued that it might be impossible to develop precise conditions for an integrated approach applicable for all industries in the EU. ${ }^{50}$ Moreover, in case an EU-wide harmonization of production emissions will be applied, this will most likely mean that a less efficient policy will be applied: market based approaches like taxation and emissions trading are assumed to lead to optimal outcomes. ${ }^{51}$ But also here, the real value of such market-based approaches has yet to be further discovered.

Part of the judicial control on the IPPC and IE directive can take place with regard to the question whether the permitting authority acted within the boundaries of its competence. In this vein, the delineation of the competence is important to consider. In order to reach a full integrative approach, the competence delineating the permit-instrument should of course enable the administrative authority to take all relevant different circumstances into account. The competence for permitting in the IPPC-directive is however not such an all-inclusive approach, as we already have seen above with regard to the greenhouse gas emissions. Another important limitation is that it is uncertain to what extent the use of raw materials can be regulated with the

\footnotetext{
${ }^{48}$ L. Krämer (2003).

${ }^{49}$ L. Krämer (2007) p. 71.

${ }^{50}$ E. Bohne (2007) p. 215

${ }^{51}$ See for an early discussion of emissions trading J.H. Dales (1968) republished in 2002 by Edward Elgar. See also B.A. Ackerman and R.B. Stewart (1988). See for a critical approach R. Baldwin (2008).
} 
permit. The use of raw materials is not included into the basic operator's obligations. ${ }^{52}$ Jongma has concluded that an efficient use of raw materials and energy is indeed not to be seen as a core purpose of the IPPC-directive. ${ }^{53}$ Nonetheless, these circumstances may play a role in the process of determination of the best available technology. ${ }^{54}$ The crucial question is: how should these circumstances exactly play a role in the permit conditions, and what are the legal limits for doing so? Can, through permitting, a prudent use of raw materials, including water, be enforced? To what extent? The European Commission also recently referred to the need to include the use of raw materials into the permitting: " The integrated approach means that the permits must take into account the whole environmental performance of the plant, covering e.g. emissions to air, water and land, generation of waste, use of raw materials, energy efficiency, noise, prevention of accidents, and restoration of the site upon closure. The purpose of the Directive is to ensure a high level of protection of the environment taken as a whole. " .55 Case law should further clarify to what extent the permitting authorities are indeed competent to include conditions in the permit that influence the use of raw materials by the operator.

\footnotetext{
${ }^{52}$ M. Doppelhammer (2000) p. 206.

${ }^{53}$ Jongma (2002).

${ }^{54}$ See Annex IV point 9 of the IPPC-directive.

${ }^{55}$ This text is take from the website of the European Commission (http://ec.europa.eu/environment/air/pollutants/stationary/ied/legislation.htm, accessed on 21 October 2012).
} 


\section{Practice}

In order to assist the permitting authorities in determining BAT under the IPPC Directive, the European Commission has published 'BAT Reference Documents' (BREFs). ${ }^{56}$ In these documents, the techniques that can be considered as BAT for specific activities are described, together with the associated emission levels. Given the key position of 'integration' in the IPPC Directive, one would expect the BREFs to reflect the integrated approach. Indeed, most BREFs do address multiple environmental issues, but usually there is a 'bias' in favour of air pollutants, whereas some aspects (such as waste and energy efficiency) receive hardly any attention in

certain BREFs. ${ }^{57}$ Several BREFs, concluded at the time of the IPPC directive, mention different techniques as (possible) BAT, leaving the choice to the permitting authority and enabling him to take local conditions and specific circumstances into account in view of art. 9(4) IPPC directive. For example, the BREF on 'Common Waste Water and Waste Gas Treatment/Management Systems in the Chemical Sector ' mentions both wet and dry waste gas treatment techniques. Wet scrubbers can achieve lower air emissions, but lead to higher amounts of polluted waste water. $^{58}$

Analysis of a sample of permits and a limited number of interviews with officials at permit issuing authorities in the Netherlands have provided us with some impressions of the

\footnotetext{
${ }^{56}$ The BREFs are published on http://eippcb.jrc.es/reference

${ }^{57}$ Oosterhuis et al. (2007), p. 69.

${ }^{58}$ EC (2003), p. 299.
} 
application of the integration approach in the practice of Dutch environmental permits. ${ }^{59}$ This analysis took place within the framework of a study for the Dutch government. The empirical basis is relatively small, and one should be aware of possible biases due to the interviewees' involvement in the permitting process. Nevertheless, a number of observations from this study are worth mentioning:

- the interpretation of the 'integration' concept differs widely; it often depends on the issues arising in particular permit cases and then tends to include only a limited number of environmental aspects;

- explicit and specific considerations on weighing different environmental aspects against each other mostly occurs in permit cases where the targets or limits for one environmental issue as specified in BREFs (or other nationally determined BAT documents) cannot be met; this is then often justified by pointing to better outcomes on another environmental issue ${ }^{60}$;

\footnotetext{
${ }^{59}$ Peeters and Oosterhuis, 2011
}

${ }^{60}$ An example is given in Peeters and Oosterhuis (2011), p. 43. In a paper plant, waste from the production process is incinerated (together with biomass). While the $\mathrm{NO}_{\mathrm{x}}$ emissions remain within the limits of the BREF Waste Incineration (EC, 2006b), they do not comply with the Dutch BAT document on waste incineration (Besluit verbranden afvalstoffen; emission limit value of $70 \mathrm{mg} / \mathrm{Nm}^{3}$, monthly average). The latter requirement would only be achievable by using Selective Catalytic Reduction (SCR), which in this specific situation was seen as too expensive and would imply additional energy consumption. The permitting authorities have therefore allowed (temporarily) a higher limit value. They did not make an explicit trade-off between $\mathrm{NO}_{\mathrm{x}}$ emissions and energy use. 
formal methods to weigh different environmental issues against each other (such as cost benefit, cost effectiveness or multicriteria analysis) are hardly used by permit practitioners, but risk analysis sometimes plays a role to set priorities;

- BREFs (including the Economics and Cross-Media Effects document) are perceived to have limited usefulness in assisting decision makers on BAT when options with different environmental impacts are possible. While they give information on the available options and relevant issues, they do not provide much guidance as to how the various aspects and impacts should be weighed against each other in concrete situations.

We did not find evidence that authorities feel hindered by the BREFs when performing their task of integrated environmental permitting. Some of them would like to have more guidance on the relative importance of different environmental issues, but at the same time they want to have sufficient freedom to do the weighing themselves, taking into account specific conditions and local circumstances.

It can be observed that under the IPPC directive the reference documents that were developed to guide decision makers in making choices that should ensure a high level of protection of the environment in an integrated way have not always succeeded in fulfilling that task. Under the IE directive, a new situation exists, in which the room for the permitting authorities has become more limited: the BAT conclusions are binding in principle, and deviations are allowed only in exceptional situations. It remains to be seen what this will mean for the permitting practitioners. The first two BAT conclusions (on glass manufacturing and on iron and steel production) were published by the Commission in March 2012. ${ }^{61}$ At first

\footnotetext{
${ }^{61}$ EC (2012a and 2012b).
} 
impression, these documents nevertheless still seem to contain some elements that leave room for discretion to the permit issuing authorities. ${ }^{62}$

\section{Conclusion}

With the adoption of the IPPC directive in 1996 the EU introduced an obligation for Member States to pursue an integrated permit approach, which means that member states were confronted with the tremendous complex question how to execute this. In the meantime, more emphasis has been put on the need to develop best available technique documents. The new IE directive gives even a stronger legal status to such documents in the permitting process. If the BAT conclusions indeed include an integrated approach, the aim of the protection of the environment as a whole is achieved in this way. The crucial question is however, whether a real integrated approach can be achieved through these technology based documents, which have an EU wide coverage. If BATconclusions do not address all the potential environmental effects of the activity, the competent authority has the task to determine the best available technology itself, and develop the permit conditions on the basis of that case specific determination of the best available technology. If however the BAT conclusion is comprehensive, the possibility for the permitting authority to take specific circumstances into account is limited. The equalization of environmental

\footnotetext{
${ }^{62}$ For example, in the BAT conclusions on glass manufacturing (EC, 2012a), Table 9 specifies BAT associated emission levels for $\mathrm{SO}_{\mathrm{x}}$ (expressed as $\mathrm{SO}_{2}$ ) from the melting furnace in the container glass sector ranging from $<500$ to $1200 \mathrm{mg} / \mathrm{Nm}^{3}$, noting that "the lower levels are associated with conditions where the reduction of $\mathrm{SO}_{\mathrm{x}}$ is a high priority over a lower production of solid waste corresponding to the sulphate-rich filter dust". Apparently, it is up to the permitting authority to decide if $\mathrm{SO}_{\mathrm{x}}$ reduction should have this priority in a specific situation.
} 
performance requirements in the EU does however not necessarily lead to optimal environmental protection, since case-specific circumstances may differ among installations throughout the EU. In this sense, European integration takes place by aligning the performance standards of industries, which not necessarily means that an optimal environmental integrative approach is being reached. In this respect, it will be interesting to see how the deviation from the BAT conclusions through permits will be used, along with the room for discretion that the BAT conclusions themselves leave to the permit issuing authorities, and how such decisions will be tested by the courts. In-depth empirical research into the real problems and challenges in the permitting practice of the authorities and the way how it is influenced by the technology based approach is necessary in order to understand whether an integrated protection of the environment as a whole will be achieved in an optimal way.

The aim of integration is however not unlimited. Under the IPPC Directive, greenhouse gas emissions have been excluded from the scope of the integrated permit, except in case such emissions may cause significant local pollution. The rationale for this exclusion is to promote the optimal functioning of the emissions trading scheme. The IE directive however seems to open the possibility for member states to introduce greenhouse gas requirements into the integrated permit. If so, it has to be considered how the greenhouse gas emissions can be balanced against other environmental effects of the installations. An integrated approach (greenhouse gas emissions into the IE permit) might however lead to a sub-optimal functioning of the emissions trading instrument. Hence, the IE directive potentially leads to a twofold suboptimal regulation: firstly because it is increasingly difficult to apply a case-specific integrative assessment, and secondly because of the potential influence on the optimal functioning of the emissions trading instrument. 
From a legal perspective, a potential advantage of a technology based approach like the IE directive is that it can be rather easily tested by courts: this contrasts with a discretionary competence for permitting authorities to reach an integrated decision by taking all kind of circumstances into account. The extent to which courts intervene into such administrative discretion remains to be examined. The discretionary approach is perhaps also more open to bargaining processes on the individual level, but at the same time it is better suited to find optimal solutions for environmental protection. The reality is that with the IE directive the technology based approach has been strengthened. However, as long as the BAT conclusions do not cover in full the environmental effects of industrial installations, it is still a task of the permitting authorities themselves to determine the best available technology in the given case. Hence, as already has been stated above, there is a need to conduct in depth research into the reality of the permitting practices under the IE directive, with the wider aim to investigate whether an integrated protection of the environment as a whole, in an efficient way, can ever become EU's practice.

\section{BIBLIOGRAPHY}

Ackerman, B.A., and R.B. Stewart (1988), Reforming Environmental Law: the Democratic Case for Market Incentives, Columbia Journal of Environmental Law, 13, 171-99.

Baldwin, R. (2008), Regulation lite: The Rise of Emissions Trading, Law Society Economy Working Papers, www.lse.ac.uk/collections/law/wps/wps.htm number 3-2008 (accessed 5 August 2013). 
Breedveld L. (2000), Dutch approach to the European Directive an Integrated Pollution Prevention and Control using life-cycle assessment for the integrated assessment of technologies, Journal of industrial ecology, 4 (2) 35-48.

Bohne, E., and D. Dietze (2004), Pollution Prevention and Control in Europe Revisited, European Environmental Law Review 13 (7) 198-217.

Bohne, E. (2008a), The implementation of the IPPC-Directive from a comparative perspective and lessons for its recast (Part 1), Journal for European Environmental \& Planning Law 5 (1), $1-33$.

Bohne, E. (2008b), The implementation of the IPPC Directive from a comparative perspective and lessons for its recast (Part II), Journal for European Environmental \& Planning Law 5 (3), 319-338.

Bréchet, T., and H. Tulkens (2009), Beyond BAT: Selecting optimal combinations of available techniques, with an example from the limestone industry, Journal of Environmental Management 90 (5), 1790-1801.

Chalmers, D., Gareth Davies, Giorgio Monti (2010), European Union Law, sec. ed. Cambridge University Press.

Dales J.H. (1968), Pollution Property and Prices: an essay in Policy-making and Economics, republished in 2002 by Edward Elgar

Dhondt, N. (2003), Integration of Environmental Protection into other EC Policies, Europa Law Publishing. 
Doppelhammer M. (2000), More difficult than finding the way round Chinatown? The IPPC Directive and its implementation, European Environmental Law Review 9 (7) p. 199-206.

EC (2003), Integrated Pollution Prevention and Control Reference Document on Best Available Techniques in Common Waste Water and Waste Gas Treatment / Management Systems in the Chemical Sector. European Commission, February 2003. http://eippcb.jrc.es/reference/BREF/cww_bref_0203.pdf (accessed 5 august 2013).

EC (2006a), Integrated Pollution Prevention and Control Reference Document on Economics and Cross-Media Effects. European Commission, July 2006 http://eippcb.jrc.es/reference/BREF/ecm_bref_0706.pdf (accessed 5 August 2013)

EC (2006b), Integrated Pollution Prevention and Control Reference Document on Best Available Techniques for Waste Incineration. European Commission, August 2006.

http://eippcb.jrc.es/reference/BREF/wi_bref_0806.pdf (accessed 5 August 2013)

EC (2010), Report from the Commission on the implementation of Directive 2008/1/EC concerning integrated pollution prevention and control and Directive 1999/13/EC on the limitation of emissions of volatile organic compounds due to the use of organic solvents in certain activities and installations, $\mathrm{COM(2010)593(def.).}$

EC (2012a), BAT conclusions for the manufacture of glass OJ L70/1, 8 March 2012.

EC (2012b), BAT conclusions for iron and steel production, OJ L70/63, 8 March 2012.

Faure, M.G., and J.G.J. Lefevere (1998), 'Integrated Pollution Prevention and Control: An Economic Appraisal'. In: Backes, C.H.R.M., Betlem, G. (red.), Integrated Pollution Prevention 
and Control. The EC Directive from a Comparative Legal and Economic Perspective, Kluwer Law International, 93-120.

Faure, M.G. and J.G.J. Lefevere, J.G.J. (1996), The Draft Directive on Integrated Pollution Prevention and Control: An Economic Perspective. European Environmental Law Review, April $1996,112-122$.

Georgopoulou, E., V. Hontou, N. Gakis, Y. Sarafidis, S. Mirasgedis, D.P. Lalas, A. Loukatos, N. Gargoulas, A. Mentzis, D. Economidis, T. Triantafilopoulos, and K. Korizi (2008), BEAsT: a decision-support tool for assessing the environmental benefits and the economic attractiveness of best available techniques in industry, Journal of Cleaner Production 16 (3), 359-373.

Guruswamy L. (1991), The case for integrated pollution control, Law and Contemporary problems 54 (4) 41-56.

Jans, J.H., and H.B. Vedder (2012), European Environmental Law, 4th ed. Europa Law Publishing.

Jongma M. (2002), De milieuvergunning. Een onderzoek naar het beschermingsniveau en de soorten voorschriften, Kluwer.

Kahn, J.R. (2005), The Economic Approach to Environmental and Natural Resources, Thomson South-Western, $3^{\text {rd }}$ edition.

Krämer L. (2003), EC Environmental Law, fifth edition, 2003 p. 160.

Krämer (2007), Better regulation for the EC environment: on the quality of EC environmental legislation, Tijdschrift voor Milieu \& Recht 34 (2) p. 70-74. 
Lange, B. (2008), Implementing EU Pollution Control. Law and Integration, Cambridge University Press.

Oosterhuis, F.H., M.G.W.M. Peeters, and R.Uylenburg, with contributions by K.F. van der Woerd (2007), Het beoordelingskader van de IPPC richtlijn. Implementatie, interpretatie en toepassing, STEM publicatie 2007/1, Structurele Evaluatie Milieuwetgeving, december 2007, ISBN 978-90-8958-135-8, retrievable at: http://arno.unimaas.nl/show.cgi?fid=20878.

Peeters, M. (2011), The EU ETS and the role of the courts: Emerging contours in the case of Arcelor, Climate Law 2, p. 19-36.

Peeters, M.G.W.M., and F.H. Oosterhuis (2011), Integrale afweging bij vergunningverlening, STEM publicatie 2010/8, Structurele Evaluatie Milieuwetgeving, februari 2011, ISBN: 978-908958-185-3, retrievable at: http://arno.unimaas.nl/show.cgi?did=25369.

Squintani L. et al. (2012), Regulating greenhouse gas emissions from EU ETS installations: what room is left for the member states? in: Marjan Peeters, Mark Stallworthy, Javier de Cendra de Larragán, Climate Law in EU Member States, Edward Elgar.

Styles, D., P. O’Brien, S. O’Boyle, P. Cunningham, B. Donlon, and M.B. Jones (2009), Measuring the environmental performance of IPPC industry: I. Devising a quantitative sciencebased and policy-weighted Environmental Emissions Index, Environmental Science \& Policy 12 (3), 226-242. 
